\title{
CHILD MARRIAGES AND THE RIGHT TO EDUCATION: THE LEGAL AND SOCIAL PERSPECTIVES
}

\author{
Maheran Makhtar ${ }^{1}$ \\ Faculty of Law \& International Relations, \\ Universiti Sultan Zainal Abidin, Terengganu, Malaysia \\ (Email: maheranmakhtar@unisza.edu.my) \\ Nor Aida Ab Kadir ${ }^{2}$ \\ Faculty of Law \& International Relations, \\ Universiti Sultan Zainal Abidin, Terengganu, Malaysia \\ (Email: aidakadir@unisza.edu.my)
}

Accepted date: $22-02-2019$

Published date: 10-07-2019

To cite this document: Makhtar, M., \& Ab Kadir, N. A. (2019). Child Marriages and The Right to Education: The Legal and Social Perspectives. International Journal of Law, Government and Communication, 4(15), 18-26.

DOI: $10.35631 /$ IJLGC.415003

\begin{abstract}
Recently, Malaysians were alarmed with the shocking news of a marriage between 11-year-old Thai girl and a 41-year-old Kelantanese man that took place in Thailand. Though the marriage was valid as it fulfilled all the requirements under Islamic Law, it could not be registered in Malaysia without the consent of a Syariah Court as the bride was below the minimum age permitted by Malaysian Law. The man was prosecuted and received a penalty, but the girl remains as a wife. Being a wife, she would shoulder a lot of responsibilities and must also be able to sacrifice a lot of things. It was reported that the man allowed the girl to continue religious schooling, but it was declined by the latter. Without sufficient knowledge and experience, the girl's future would solely depend on her husband and the parent. Thus, this research paper aims to study on the issue of child marriages in Malaysia and how it would affect children legally and physiologically. This paper also intends to examine on the right to education with special reference to married children. This research paper adopts qualitative methodology by examining relevant statutory provisions, decided cases, international treaties and articles from selected journals. It is therefore suggested that special care should be placed on the married children, particularly on their right to education and their right to be able to hold the future at their own hands.
\end{abstract}

Keywords: Right To Education-Children-Marriage

\section{Introduction}

A child is defined as any person below the age of 18 years old (section 2, Age of Majority Act 1971). As children, they shall enjoy all the rights available to them namely the right to security of person, the right to be protected, the right to all basic needs and necessities, the right to freedom from torture and most importantly, the right to life (Unicef Canada, 2010). Every 
human being including children is entitled to the right to life. For children, the right to life is the chance to be able to live and have the possibility to grow, to develop and become adults. It is therefore argued that when a child enters a marriage union, his/her right to life is infringed by the reason that he/she is not given the chance to develop normally but instead, is forced to grow to be an adult in a child's body; physically and mentally. The Committee on the Rights of the Child (CRC) characterizes 'child marriage' as any marriage where either one or both accomplices are beneath 18 years old'. The United Nations Population Fund (UNFPA) in collaboration with the United Nations Children's Fund (UNICEF) defined child marriage as "a formal marriage or casual cohabitation before the age of 18". (United Nations Population Fund, n.d.). It was reported that between 2007 and 2017, there were 10, 000 Muslim marriages involving children with adults and 4, 999 non-Muslim marriages involving children with adults been registered (Malaysia Department of Social Welfare). In addition, United Nations has cited the report from Joint Action Group for Gender Equality (JAG) which stated that there were approximately 15, 000 Malaysians who were married off before attaining the age of majority which is 18 (Malay Mail Online, 2015).

Child marriage has been and still is, a subject of debate among people around the world. While many human rights activists are against the idea of children normally girls, entering into the most sacred union, there are still many of us who believe that it is acceptable as girls, in one way or another would end up in marriages. Therefore, adopting qualitative method by analysing documentary materials, the objective of this paper is to examine the legal framework on child marriage in Malaysia, both in Islamic law and civil law and to study the consequence of child marriage on the right to education, which is a fundamental right under the Universal Declaration of Human Rights.

\section{The Legal Framework on Child Marriage in Malaysia}

According to the Islamic Family Law Enactment which applies in all states, the minimum legal age for marriage is 18 years for a male and 16 years for a female. Those under the legal minimum age will only be permitted for marriage if they obtain consent from the Syariah court as well as from their parents. Section 8 of the Islamic Family Law (Federal Territories) Act 1984 stated the provision of minimum age for marriage as follows:

8. No marriage may be solemnized under this Enactment where either the man is under the age of eighteen or the woman is under the age of sixteen except where the Syariah Judge has granted his permission in writing in certain circumstances.

Under the civil law, male below the age of 18 are not allowed to marry. However, for female, permission of the Chief Minister of the state is required if the girl is below 18 but if the girl is below 16, this exception is not applicable. In either case, any marriage below the age of 21 requires the parents' consent.

The Law Reform (Marriage and Divorce) Act 1976 which applies across the board lays down provisions for underage marriage as follows:

10. Any marriage purported to be solemnized in Malaysia shall be void if at the date of the marriage either party is under the age of eighteen years unless, for a female who has completed her sixteenth year, the solemnization of such marriage was authorized by a licence granted by the Chief Minister under subsection 21(2). 
Section 21(2) states:

21. (2) The Chief Minister may in his discretion grant a licence under this section authorizing the solemnization of a marriage although the female party to the marriage is under the age of eighteen years, but not in any case before her completion of sixteen years.

Both laws did not specify the exact criteria in which an underage child can marry. This is because the civil laws use the phrase "at his discretion" while the Islamic Family law says, "in certain circumstances" and leaves this decision to the Chief Minister or to the Syariah judge. While it can be argued that this can be vague, it also allows the decision-maker to take into account the reasons for that particular marriage; along with current social and cultural considerations before allowing or disallowing it.

However, it's also worth noting that the National Fatwa Committee answered the question of child marriage for Muslims in a 2014. The Fatwa concluded that an underage marriage can only be permitted if it is for the best interest of the child. Additionally, they also recommended that the authorities restrict the conditions of child marriage and ensure that procedures are being followed (Nazar, 2014). This Fatwa can be seen as a way to address child marriage based on the current social and cultural concerns. On the civil side, certain laws have been introduced that can be seen as progressively taking the interests of the child into consideration, such as the Sexual Offences Against Children Act 2017 which protects children against the recent concern of sexual predators and child grooming.

\begin{tabular}{|c|c|c|c|c|}
\hline \multirow{2}{*}{$\begin{array}{l}\text { The Legal } \\
\text { System }\end{array}$} & \multicolumn{2}{|c|}{ Minimum Age Requirement } & \multicolumn{2}{|l|}{ Exception } \\
\hline & Male & Female & Male & Female \\
\hline Islamic Law & $\begin{array}{l}18 \\
\text { (Section } 8 \\
\text { IFLA). }\end{array}$ & $\begin{array}{l}16 \\
\text { (Section } 8 \\
\text { IFLA). }\end{array}$ & $\begin{array}{l}\text { Shariah Courts } \\
\text { may grant its } \\
\text { written } \\
\text { permission } \\
\text { under } \\
\text { certain } \\
\text { circumstances. } \\
\text { (Section } 8 \\
\text { IFLA). }\end{array}$ & $\begin{array}{l}\text { Shariah Courts } \\
\text { may grant its } \\
\text { written } \\
\text { permission } \\
\text { under certain } \\
\text { circumstances } \\
\text { (Section } 8 \\
\text { IFLA) }\end{array}$ \\
\hline Civil Law & $\begin{array}{l}18 \\
\text { (parental } \\
\text { consent } \\
\text { required } \\
\text { for those under } \\
21 \text { ) } \\
\text { (Section } 10 \\
\text { LRA). }\end{array}$ & $\begin{array}{l}18 \\
\text { (parental } \\
\text { consent } \\
\text { required for } \\
\text { those } \\
\text { under 21) } \\
\text { (Section } 10 \\
\text { LRA) }\end{array}$ & Nil. & $\begin{array}{l}\text { The Chief } \\
\text { Minister of } \\
\text { various states } \\
\text { may grant a } \\
\text { licence to } \\
\text { authorize the } \\
\text { solemnisation } \\
\text { of marriage for } \\
\text { those } \\
\text { between the } \\
\text { ages of } 16 \text { and } \\
\text { 18. } \\
\text { (Section } 10 \\
\text { LRA) }\end{array}$ \\
\hline
\end{tabular}

Table 1: Minimum Age Requirement for Marriage in Islamic law and Civil law 
In Malaysia, a total of 968 marriages involving non-Muslim children and adults and 147 marriages between children were registered nationwide last year. Meanwhile, a total of 5,362 applications for permission to proceed with Muslim child marriages were registered with the Syariah courts between 2013 and last year. According to Malaysia Department of Welfare (JKSM) data, the approval rate in 2015 was $81 \%$. This does not vary much from the approval rates in $2011(86.1 \%), 2012(87.7 \%)$ and 2014 (74\%). Out of ten child marriage applications, therefore, the Shariah court judge approved eight on average. However, the approval rate for underage non-Muslim marriage applications from 2015 onward are unavailable (Ooi , 2017).

\begin{tabular}{|l|l|}
\hline States & Statistics \\
\hline Sarawak & 918 \\
\hline Sabah & 793 \\
\hline Kelantan & 793 \\
\hline Johor & 440 \\
\hline Terengganu & 407 \\
\hline Kedah & 389 \\
\hline Selangor & 385 \\
\hline Pahang & 354 \\
\hline Perak & 266 \\
\hline Federal Territory & 178 \\
\hline Negeri Sembilan & 155 \\
\hline Perlis & 107 \\
\hline Melaka & 91 \\
\hline Penang & 86 \\
\hline
\end{tabular}

Table 2: Statistic of Application for Permission to Marry Below the Minimum Age in Syariah Courts, Between the Year of 2013 and 2017

Source: (New Straits Times, 2018)

Universal Declaration of Human Rights (UDHR) has no direct provision on child marriage but it has recognized that 'marriage shall be entered only with the free and full consent of the intending spouses' [article 16(2)] and 'men and women of full age...' are entitled to equal rights as to marriage [article 16(2)]. In addition, the Convention on the Elimination of all Forms of Discrimination against Women (CEDAW) also mentions that "The betrothal and the marriage of a child shall have no legal effect, and all necessary action, including legislation, shall be taken to specify a minimum age for marriage..." (article 16). While marriage is not considered directly in the Convention on the Rights of the Child, child marriage is linked to other rights, such as the right to express their views freely, the right to protection from all forms of abuse, and the right to be protected from harmful traditional practices. Malaysia has ratified all the above-mentioned treaties.

Hence, by the wordings of the international treaties, child marriage is a form of human right violation. It also suggests that a child is not capable of giving free and full consent to enter into a contract (section 11 of the Contracts Act 150) and thus, are not encouraged to enter into a marriage union. By the general rule, a contract entered by a child is void for reason for incapacity. However, the court has specifically dealt with the issue of child marriage in Malaysia. In the case of Rajeswary V Balakrishnan (1958) 3 MC 178, the court held that contracts to marry entered into by a minor are distinguishable from other classes of contracts. 
Section 4(a) of the Majority Act 1971 recognizes that a child is regarded as competent in the following cases namely marriage, divorce, dower and adoption

\section{The Right to Education in Malaysia}

Education is seen as an important element for the development of a child. The Malaysian Child Act 2001 recognizes the that every child is entitled to protection and assistance in all circumstances without regard to distinction of any kind, such as race, colour, sex, language, religion, social origin or physical, mental or emotional disabilities or any other status. In addition to that, Article 3 of the Convention on Right of Child 1989 (CRC) provides that the best interests of the child shall be a primary consideration in all actions affecting children.

The international community now recognizes the importance of education for the economic, social, and physical well-being of children, their family members, and society at large. Article 26 of the Universal Declaration of Human Rights states that the right to education should be available to everyone and that primary education should be made free and compulsory. A similar provision can also be found in article 28 of the CRC, which Malaysia has acceded to in 1995. It provides that primary education should be made compulsory and higher education should be made available and accessible to every child.

In Malaysia, article 12 of Malaysian Federal Constitution provides for the right in respect to education to all citizens in Malaysia whereby the provision guarantees that no citizen shall be discriminated on the ground of religion, race, descent or place of birth in the admission to public schools or in the payment of fees. It is then codified in the Education Act 1996 which provides that the government may publish in the Gazette to prescribe for primary education to be a compulsory education. In 2003, Malaysian government had gazette for compulsory primary education in the Professional Circular No. 14/2002: Implementation of Compulsory Education in Primary Level in 2003, dated 27th November 2002. Thus, from the legislations, all citizens of Malaysia must send their children to school for the compulsory elementary education, ranging from age 7 to 12 years old. The Education Act 10996 also provides for criminal liability for parents who fail to send their children to school, though this provision is never utilized. As far as secondary and tertiary education is concerned, the Education Act 1996 makes these two levels of education as recommendable and optional. Though these two levels are recommended but higher education is seen to be the most important level of education as it would give opportunity for children to create a better future. This level is the most cost consuming level of education especially when the children embark in private institution. Without proper financial aid from the parents, the children would face great challenges to embark themselves in education and would opt for labour hood at the early age.

In 2012, the Malaysian government had announced the abolishment of school fees in both elementary and secondary public schools with the aim of providing access to quality and affordable education to every child irrespective of their socio-economic background. This announcement is perceived as a good development in Malaysia, following the recommendation of UDHR and CRC that promotes free and compulsory education, at least at the elementary level. Assessing that the cost of education in Malaysia is not simply by looking at the school fees, these announcements relieve less than half of financial problems faced by the parents. Other costs such as school uniforms, extra reading materials, pocket money for meals, transport fare are among other indirect costs that parents should bear when sending the children to schools. Thus, a financially constraint single parent may find this a heavy burden especially when their children are more than two, all at once are in schooling age. 
The right of education is also one of the rights provided in Islam. The importance of knowledge is emphasized in Surah al-Alaq which reads: "Read in the name of your Lord who created, created man from a clinging form. Read! Your Lord is the Most Generous, who taught by means of the pen; taught man what he did not know" (Al-Alaq: 1-5). In another surah, Allah has mentioned: "(This is) a Book (the Quran) which We have sent down to you, full of blessings that they may ponder over its Verses, and that men of understanding may remember" (Sad:29)

The Prophet Muhammad (peace be upon him) said: "If anyone travels on a road in search of knowledge, God will cause him to travel on one of the roads of Paradise. The angels will lower their wings in their great pleasure with one who seeks knowledge. The inhabitants of the heavens and the Earth and (even) the fish in the deep waters will ask forgiveness for the learned man. The superiority of the learned over the devout is like that of the moon, on the night when it is full, over the rest of the stars. The learned are the heirs of the Prophets, and the Prophets leave (no monetary inheritance), they leave only knowledge, and he who takes it takes an abundant portion. (Sunan of Abu-Dawood, Hadith 163). These three authentic sources among abundance more prove that education is very much important in Islam and Muslims are encouraging to seek for it.

\section{Effect of Child Marriages to Children's Future Wellbeing}

Though child marriage is not specifically protected under the CRC, one must consider the other rights that are guaranteed which goes side by side with the issue of child marriage namely, the right to life, the right to education, the right to health and the right to survival (among others) (Melchiorre, 2004). In any issue concerning children, whether undertaken public or privately, the best interest of a child is the overriding factor to be considered (Article 3, CRC). However, in making decision particularly which involves parental supervision, the best interests of the child cannot normally be the only consideration but should be among the first aspects to be considered and should be given considerable weight in all decisions affecting children (Hammarberg, 2008).

The best interest of a child may differ from one era to another, resources, the developmental level and the culture of the country in which the child lives. In a particular culture, one might consider that it is more important for a child especially the female ones to learn how to manage household rather than to receive education (Hammarberg, 2008). Malaysian has for so long forgo this traditional culture. While it is true that women are more incline towards family rather than self-fulfilment but research has shown that women who are educated are healthier, participate more in the formal labor market, earn more income, have fewer children, and provide better healthcare and education to their children compared to women with little or no education (Hirschman, 2016) (McCleary-Sills, Hamner, Parson, \& Klugman, 2015). The benefits of education transmit across generations as well as to communities at large. Where girls have greater educational and economic opportunities, they are more likely to pursue those opportunities than to have children in their teenage years. The essence of the rights to education and to health is that they facilitate and ensure the effective enjoyment of other human rights (Bayisenge).

Lack of education is both the factor and outcome of an early marriage (Klugman, et al., 2014) (Ooi , 2017) It was reported that low household income, lack of parenting support interventions, lack of access to education and lack of access to sexual and reproductive health education were among the factors of early marriages in Malaysia (Mohd Awal \& Samuri, 2018). Many Muslims enter into child marriage for reasons of rape, voluntary sexual intercourse or unwanted pregnancy. (Protect \& Save the Children Association of Selangor \& Kuala Lumpur, 2013). The fear for public humiliation and by reason of protecting the dignity of child born out-of-wedlock 
or simply for religious purposes are the normal justifications for permitting child marriage (Unicef, 2015) (World Health Organization, 2011). As a result, the child could suffer either physical or mental abuse, receive harsh treatment from in-laws, and face resentment from husband especially when the husband himself is a young man and even divorce (Ooi, 2017). Apart from the child 'willingness' to get married, many parents were reported to marry off their girls due to financial constraints (Bernama, 2016) as well as to ensure their daughters' financial security (M.Nour, 2006). Gender inequality in the family or simply because parents could not afford to bear the cost any longer, marrying off a daughter would allow them to reduce family expenses by ensuring they have one less person to feed, clothe and educate and also investing in their son's education as more worthwhile investment. In some cases, marriage of a daughter is a way to repay debts, manage disputes, or settle social, economic and political alliances (International Center for Research on Women (ICRW), 2016).

After the marriage, young girls' access to formal and even non-formal education is severely limited because of domestic burdens, childbearing and social norms that view marriage and schooling as incompatible (International Center for Research on Women, 2016). Research has found that girls who marry early are significantly less likely to complete their secondary school education, which in turn lowers the potential earnings they can make as adults and thereby reduces their family's economic potential. Moreover, child marriage and lower educational attainment creates ripples into the next generation by diminishing the educational prospects for children of child brides. In other words, child marriage may be playing an important role in perpetuating poverty (John, 2018). Clearly, investing in girls' education can have a tremendous impact on reducing child marriage and therefore in reducing poverty for families, communities, and countries.

In sociological aspect, many young girls who are married are reported to have lack of decision making within the family as they are still seen and considered as young (Parsons et al, 2015). Due to the fact that they would rely on adult (husband) for economy support, young girls would not be able to have much a say in their marital relationship, including to make decisions for the own children. In addition, girls who marry early are more likely to be exposed to risk of abuse and violence by the husband which would certainly lead psychological and physical consequences (Adedokun, Adeyemi \& Dauda, 2016). In certain cases, child marriage will lead to early pregnancy-health complications and effect on sexual health of young girls and impairment on social development (Ahmad Sofi, 2017) although some reported that it was also a protective mechanism against premarital sexual activities, unintended pregnancies and sexually transmitted diseases (STDs) (M.Nour, 2006).

\section{Conclusion}

For the best interests of the child to be determined, it is important that the child himself or herself be heard. With increased age and maturity, the child should be able to influence and decide more. This obvious point is often forgotten. Adults tend to discuss what is best for children without seeking their opinions or even listening to them.

One of the solutions proposed is by empowering girls with information, skills, and support networks as well as programs to educate the parents and community members on the importance of education to children especially girls. Government should also take a proactive measure by legislating a supporting laws and policies to overcome the issue and to provide for economic support and incentives to girls and the families (International Center for Research on Women (ICRW), 2016). It is also suggested that the Shariah court judge or the Menteri Besar / Chief Minister to exercise wise discretion in approving child marriages and consider granting permission for the best interest of the child. There are number of steps proposed before the 
Shariah Court judge or the Menteri Besar/Chief Minister could grant the permission. Firstly, medical report on the child's physical must be tendered and review by the court/Menteri Besar/Chief Minister; secondly, a child psychologist evaluation and/or counselling report; thirdly a single one-on-one session with the child and fourthly, to open up platform for objections either by the child's immediate paternal or maternal relatives, a government officer above a certain rank in the Welfare Department, or a social worker with demonstrable grounds for objection. It was further recommended that if the child is not pregnant, the duration of the procedure could be lengthen so that proper consideration can be done, and if there is a slightest hint of sexual abuse and unwillingness on the part of the child, the judge or the Menteri Besar / Chief Minister should not hesitate to throw out the application and order a police investigation instead. (Ooi, 2017)

\section{References}

Adedokun, O., Adeyemi, O., \& Dauda,C. (2016). Child marriage and maternal health risks among young mothers in Gombi, Adamawa State, Nigeria: implications for mortality, entitlements and freedoms. African Heath Sciences. US National Library of Medicine, National Institutes of Health. Vol 16(4). doi: 10.4314/ahs.v16i4.15

Ahmad Sofi. M. (2017). Child marriage as a social problem and its impacts on the girl child. International Journal of Advanced Education and Research, Vol 2(4). India

International Center for Research on Women. (2016). Child Marriage and Education. Washington, DC: International Center for Research on Women.

Bayisenge, J. (n.d.). Early Marriage as a Barrier to Girl's Education: A Developmental Challenge in Africa. Africa: National University of Rwanda

Bernama. (2016, May 21). Poverty Primary Factor For Child Marriage. Retrieved from Astro Awani: http://english.astroawani.com/malaysia-news/poverty-primary-factor-childmarriage-105896

Hammarberg, T. (2008). The Principle of the Best Interest of the Child-What it Means and What it Demands from Adult. Strasbourg: Commissioner for Human Rights, Council of Europe.

Hirschman, C. (2016). Gender, the Status of Women, and Family Structure in Malaysia. Malaysian Journal of Economic Studies, 53(1), 33-50.

International Center for Research on Women (ICRW). (2016). Taking Action to Address Child Marriage: The Role of Different Sectors; An Overview. Washington, DC and United Kingdom: The Global Partnership to End Child Marriages.

John, N. (2018, January 28). Is Girls Education The Key To Ending Child Marriage? Retrieved from Women Deliver: https://womendeliver.org/2018/girls-education-key-endingchild-marriage/

Klugman, J., Hamner, L., Twigg, S., Hasan, T., McCleary-Sills, J., \& Santamaria, J. (2014). Voice and Agency: Empowering Women and Girls for Shared Prosperity. WashingtonDC: World Bank Group.

M.Nour, N. (2006). Health Consequences of Child Marriage in Africa. Emerging Infectious Diseases, US National Library of Medicine, National Institutes of Health. Vol 12(11). doi: 10.3201/eid1211.060510

Malay Mail Online. (2015, October 2nd). Child marriages not rare in Malaysia with 15,000 underage brides, activists say. Retrieved from Malay Mail Online: https://www.malaymail.com/s/980543/child-marriages-not-rare-in-malaysia-with15000-underage-brides-activists-s

McCleary-Sills, J., Hamner, L., Parson, J., \& Klugman, J. (2015). Child Marriage: A Critical Barrier to Girls' Schooling and Gender Equality in Education. Journal The Review of Faith and International Affairs, Vol.13 (3). 
Melchiorre, A. (2004). At what age? are school children employed, married and taken to court? Sweden: Swedish International Development Agency, Sida.

Mohd Awal, N., \& Samuri, M. (2018, July 20). Child Marriage in Malaysia. Selangor: Unicef Malaysia. Retrieved from Four Main Motivators of Child Marriage Identified in Malaysia: http://www.theborneopost.com/2018/07/20/four-main-motivators-of-childmarriage-identified-in-malaysia/

National Report: Malaysia. (2018). Child Marriage: Its Relationship with Religion, Culture and Patriarchy. Selangor: Sisters in Islam (SIS) and Asian-Pacific Resource and Research Centre for Women (ARROW).

Nazar, H. (2014, December 1). Child marriages do more harm than good, says Fatwa Council. Retrieved from The Rakyat Post News: http://www.therakyatpost.com/news/2014/12/01/child-marriages-harm-good-saysfatwa-council/

New Straits Times. (2018, July 19). Close to 1,000 non-Muslim adults and children marriages registered in 2017. Retrieved from New Straits Times: https://www.nst.com.my/news/nation/2018/07/392274/close-1000-non-muslimadults-and-children-marriages-registered-2017

Ooi, K. (2017). Child Marriages in Malaysia: Reality, Resistance. Penang: Penang Institute Issues.

Parsons,J, Edmeades, J, Kes, A, Petroni, S, Sexton, M and Wodon, Q. (2015). Economic Impacts of Child Marriage: A Review of the Literature. The Review of Faith \& International Affairs, 13:3, 12-22, DOI: 10.1080/15570274.2015.1075757

Protect \& Save the Children Association of Selangor \& Kuala Lumpur. (2013). Child Marriage - Situation in Malaysia. Kuala Lumpur: Protect \& Save the Children Association of Selangor \& Kuala Lumpur.

Unicef. (2015). Child Marriage and Adolescent Pregnancy in Mozambique: Causes and Impact. Maputo, Mozambique: UNICEF.

Unicef Canada. (2010). Children's Rights and Responsibilities; Summary on UN Convention on Right of the Child. Canada: Sri Utami.

United Nations Population Fund. (n.d.). Child Marriage. Retrieved from United Nations Population Fund: https://www.unfpa.org/child-marriage

World Health Organization. (2011). Early marriages, adolescent and young pregnancies. World Health Organization. 